\title{
ANALYSIS OF SELECTED PHYSICO-CHEMICAL PARAMETERS OF TWO PONDS OF MADHUBANI NUSRAT ARA ${ }^{\text {a1 }}$ AND SHAHNAZ JAMIL ${ }^{b}$
}

\author{
${ }^{\mathrm{ab}}$ Department of Botany, M.L.S.M. College, L.N.M University, Darbhanga, Bihar, India
}

\begin{abstract}
Present study was aimed to observe the monthly variations in selected physico-chemical parameters of surface water of two perennial ponds of Madhubani district of Bihar state. Selected parameters were determined for one year that is from January to December in 2018. The maximum value of water $\mathrm{pH}$, temperature, turbidity, alkalinity, transparency, total dissolved solids, dissolved oxygen, free carbon dioxide, Biological Oxygen Demand, Chemical Oxygen Demand, Chloride contents Nitrates and Calcium and Total hardness of the pond situated near R.K. College, Madhubani were found as 8:5, 35 $\mathrm{c}$, 48.0, 158.74, $150.0 \mathrm{~cm}, 1270 \mathrm{mg} / \mathrm{l}, 852 \mathrm{mg} / \mathrm{l}, 7.38 \mathrm{mg} / \mathrm{l}, 42.28,58.74,29.62 \mathrm{mg} / \mathrm{l}, 8.34 \mathrm{mg} / \mathrm{l}, 48.64 \mathrm{mg} / \mathrm{l}, 151.60 \mathrm{mg} / \mathrm{l} \mathrm{respectively}$, while the maximum values of same parameters of an abandoned pond were, $8.3,36^{\circ} \mathrm{c}, 46.0,155.18,142 \mathrm{~cm}, 1228 \mathrm{mg} / 1,8.62$ $\mathrm{mg} / \mathrm{l}, 7.46 \mathrm{mg} / \mathrm{l}, 42.78,59.58,31.24 \mathrm{mg} / \mathrm{l}, 9.52 \mathrm{mg} / \mathrm{l}, 49.85 \mathrm{mg} / \mathrm{l}$, and $146.62 \mathrm{mg} / \mathrm{l}$. Present study indicates the existing health of these two perennial water bodies being used by the local people. Based on the above data suitable measures may be taken by the administrators to reduce the different loads of pollutant to maintain the purity of these perennial resource of water bodies.
\end{abstract}

KEYWORDS: Physico-chemical Parameters, Monthly Variations, Abandoned, Perennial, Water Bodies, Pollutants

Water was essential for the origin of life on this earth and it is an essential component for the survival of the life on this planet. Out of the total water present on this earth 96.5 percent is the sea water and is not directly used for any purpose. 1.7 percent is in the form of glacier, and 1.7 percent is ground water only $0.1 \%$ of water is available for all of the process of living beings (Durge et al., 2018). Water in nature is always pure, but due to anthropogenic activities, its purity is being lost. Unrestrained increase in human population and rapid urbanization and industrialization in all over the world is placing great stress up on fresh water resources. (Bano et al., 2016). Village ponds were the only source of perennial water among the villagers, but due to urbanization, these water bodies are being used as a sink for the dumping of domestic wastes, discharge of sewage and being used for washing clothes and animals only.

Due to such anthropogenic pressures, the water quality of such ponds is being distressed and polluted. The deterioration of water of such ponds has reached at alarming conditions. Not only this during rainy season's different agro-chemicals used by the farmers in their fields being deposited in these ponds along with runoff water. Local people who are using this pond water do not know about the health of such pond water. It is therefore, essential that there should be frequent test and analysis of such water bodies. The quality of water is characterized by different physico-chemical parameters. These parameters are not constant as they change in different seasons because of the input of rain water, which may carry different pollutants and nutrients along with it. It also depends on the local human intervention (Parikh and Mankodi, 2012).

Physico-chemical analysis of different water bodies have been done by different workers. Results of these works are eye opener. Some of them may be cited here, Pejawar et al., (2004), Charkhabi and Sakizadeh (2006), Smitha et al., (2007), Kiran (2010), Mahananda et al., (2010), Singh (2010), Biswas et al., (2011), Kedar and Patil (2011), Srivastva and Srivastva (2011), Barai and Kumar (2012), Sahni and Sheela (2012), Verma et al., (2012), Tirupathaiah et al., (2012), Bhatnagar and Devi (2013), Mishra et al., (2013), Mohan et al., (2013), Patel and Parikh (2013), Prasath et al., (2013), Srivastva and Kanungo (2013), Tank and Chippa (2013), Yadav et al., (2013), Mazumdar and Dutta (2014), Mishra et al., (2014), Nag and Gupta (2014), Singh (2014), Dixit et al., (2015), Paul et al., (2015), Reddy et al., (2015), Qureshimatva et al., (2015), Swarnkar and Chaubay (2016), Uddin et al., (2016), Balkrishnan et al., (2017), Goswami et al., (2017), Rahman et al., (2017), and Durge et al., (2018). Keeping these ideas in mind the present work was planned to study the physico-chemical parameters of two ponds of Madhubani district.

\section{MATERIALS AND METHODS}

\section{Study Area}

For the present work tow ponds, situated in Madhubani were selected one pond near R.K. College, and other outside the town area which is virtually abandoned. 
The pond near R.K. College receives large amount of allochthonous matter, from the surroundings, where as the pond outside the town gets different agrochemical from the surrounding agricultural lands during the rainy seasons. The geographical location of these ponds situated in Madhubani is at a longitude of $25^{\circ}-59^{\prime}$ to $26^{0}-39^{\prime}$ East and the latitude is $85^{\circ}-43^{\prime}$ to $86^{\circ}-42^{\prime}$ North. Here the rain fall varies between $900 \mathrm{~mm}$ and $1300 \mathrm{~mm}$. Average rainfall is $1273.2 \mathrm{~mm}$.

Sampling of pond water was done monthly for one year. The standard methods suggested by APHA (2005) were followed. Water samples were collected during the early hours (9:45-10:45 AM) form different parts of the ponds. They were mixed for the study of different parameters. Physical parameters such as $\mathrm{pH}$, temperature and transparency were studied at site, where as turbidity and total dissolved solids and alkalinity was studied in laboratory. Similarly, dissolved oxygen, free carbon dioxide, Biological oxygen demand, chemical oxygen demand, concentrations of chloride, nitrate, calcium, total hardness were studied in the laboratory. $\mathrm{pH}$ was measured with the help of $\mathrm{pH}$ meter and temperature with Celsius-thermometer graduated up to $110^{\circ} \mathrm{C}$.

Transparency was measured with the help of Secchi disc. Turbidity was measured using Nephelometer (Systronics digital nephelo turbidity meter), Dissolved oxygen was calculated using standard Winkler's titration method. Free carbon dioxide was calculated by doing titration of sample water with $0.02 \mathrm{NaOH}$, using Phenolphthalein as indicator. Biochemical oxygen demand was calculated using 5 days incubation process. Chemical oxygen demand was calculated using condensation digestion and titration method. Alkalinity, chloride and total hardness were calculated by titration methods. All the experiments were done in triplicate and the mean of the data was used for discussion.

\section{RESULTS AND DISCUSSION}

Data obtained from the above experiments have been represented by table 1 and table 2 for the physical and chemical parameters.

Table 1: Monthly variations in selected physico-chemical parameters of pond water of R.K. College, Madhubani

\begin{tabular}{|c|c|c|c|c|c|c|c|c|c|c|c|c|}
\hline Parameters & Jan & Feb & Mar & Apr & May & Jun & Jul & Aug & Sept & Oct & Nov & Dec \\
\hline pH & 8.5 & 8.2 & 7.8 & 7.9 & 8.3 & 7.7 & 8.0 & 7.8 & 7.4 & 7.6 & 7.4 & 7.5 \\
\hline Temp. & 15.0 & 17.0 & 19.0 & 20.0 & 31.0 & 35.0 & 32.0 & 30.0 & 28.0 & 28.0 & 24.0 & 19.0 \\
\hline $\begin{array}{c}\text { Turbidity } \\
\text { NTU }\end{array}$ & 36.0 & 38.0 & 35.0 & 40.0 & 48.0 & 46.0 & 44.0 & 42.0 & 39.0 & 38.0 & 35.0 & 37.0 \\
\hline Alkalinity & 133.62 & 129.45 & 134.64 & 131.52 & 141.18 & 133.56 & 153.35 & 156.48 & 146.62 & 158.74 & 155.86 & 151.71 \\
\hline Transparency & 150.0 & 130.0 & 140.0 & 120.0 & 58.0 & 50.0 & 56.0 & 68.0 & 90.0 & 96.0 & 105 & 118 \\
\hline TDS mg/l & 1187.0 & 988 & 1070 & 1166 & 1078 & 1284 & 1270 & 1078 & 970 & 948 & 978 & 1035 \\
\hline DO mg/l & 8.52 & 8.41 & 8.15 & 7.40 & 5.80 & 4.76 & 6.42 & 7.50 & 7.80 & 8.15 & 8.30 & 8.38 \\
\hline BOD & 28.36 & 30.65 & 32.40 & 38.54 & 42.28 & 40.62 & 39.58 & 37.74 & 36.25 & 35.18 & 33.64 & 30.72 \\
\hline COD & 38.85 & 42.28 & 44.36 & 48.54 & 52.66 & 58.74 & 54.24 & 53.78 & 50.55 & 48.38 & 48.18 & 44.86 \\
\hline Chloride mg/l & 28.74 & 26.45 & 23.28 & 21.65 & 20.18 & 20.78 & 15.78 & 16.40 & 19.18 & 21.25 & 24.38 & 29.62 \\
\hline Nitrate & 2.56 & 2.74 & 2.48 & 2.62 & 2.68 & 2.35 & 2.74 & 5.46 & 8.34 & 7.82 & 6.78 & 5.46 \\
\hline $\mathrm{Ca}^{++}$ & 38.42 & 36.58 & 35.75 & 34.68 & 34.34 & 33.16 & 32.74 & 48.64 & 44.18 & 45.62 & 38.50 & 36.75 \\
\hline $\begin{array}{c}\text { Total } \\
\text { Hardness }\end{array}$ & 78.54 & 72.38 & 86.46 & 108.62 & 138.46 & 151.60 & 142.44 & 136.18 & 131.72 & 122.38 & 114.74 & 82.36 \\
\hline Free $\mathrm{CO}_{2}$ & 4.56 & 5.82 & 6.48 & 6.56 & 6.78 & 7.38 & 6.64 & 6.48 & 6.41 & 6.24 & 5.72 & 5.38 \\
\hline
\end{tabular}

pH

It is a measure of hydrogen ion concentration of the water body. The acidity and alkalinity of water may be determined due to its concentration. From the table 1, it may be noted that $\mathrm{pH}$ of the pond near R.K. College, Madhubani ranged between 7.4 to 8.5 . The $\mathrm{pH}$ of pond water was slightly alkaline. Highest range 8.5 was found in the month of January, which decreased in summer. Decrease in $\mathrm{pH}$ during rainy season may be due to increase in volume of water of the pond.
Similar, trends for $\mathrm{pH}$ was also found in the pond water situated out of the town in Madhubani. However, here maximum value was 8.3 while the minimum 7.4. $\mathrm{pH}$ is associated with the rate of photosynthesis of the aquatic plants. Increased $\mathrm{pH}$ value in winter and low in summer have been reported by Singh (2010), Sahni and Yadav (2012), Goswami et al., (2017), Bhattacharyya (2018). Therefore, findings of the present work corroborate with the above findings. However, Sahni and Yadav (2012) reported higher range of $\mathrm{pH}$ during summer. 
ARA AND JAMIL: ANALYSIS OF SELECTED PHYSICO-CHEMICAL PARAMETERS OF TWO PONDS OF MADHUBANI

Table 2: Monthly variations in selected physico-chemical parameters of pond of Madhubani abundant

\begin{tabular}{|c|c|c|c|c|c|c|c|c|c|c|c|c|}
\hline Parameters & Jan & Feb & Mar & Apr & May & Jun & Jul & Aug & Sept & Oct & Nov & Dec \\
\hline $\mathrm{pH}$ & 8.3 & 8.1 & 7.6 & 7.8 & 8.1 & 7.6 & 8.0 & 7.6 & 7.4 & 7.5 & 7.4 & 7.6 \\
\hline Temp. & 14 & 16 & 18 & 21 & 32 & 36 & 34 & 32 & 31 & 27 & 26 & 17 \\
\hline $\begin{array}{c}\text { Turbidity } \\
\text { NTU }\end{array}$ & 34.0 & 36.0 & 34.0 & 38.0 & 46.0 & 43.0 & 42.0 & 40.0 & 38.0 & 36.0 & 33.0 & 34.0 \\
\hline Alkalinity & 131.78 & 127.64 & 132.58 & 130.28 & 138.34 & 131.26 & 149.62 & 151.24 & 143.56 & 155.18 & 152.36 & 147.68 \\
\hline Transparency & 142.0 & 124.0 & 136.0 & 115.0 & 50.0 & 48.0 & 51.0 & 62.0 & 74.0 & 82.0 & 98.0 & 118.0 \\
\hline TDS mg/l & 1125.0 & 961.0 & 1015.0 & 1018.0 & 1022.0 & 1228.0 & 1198.0 & 1010.0 & 915.0 & 889.0 & 915.0 & 998.0 \\
\hline DO mg/l & 8.68 & 8.54 & 8.28 & 7.52 & 5.24 & 4.18 & 6.12 & 7.36 & 7.30 & 8.25 & 8.46 & 8.52 \\
\hline BOD & 28.58 & 31.24 & 33.56 & 38.82 & 42.78 & 41.28 & 40.34 & 39.56 & 38.34 & 36.55 & 34.72 & 31.65 \\
\hline COD & 39.64 & 43.54 & 45.74 & 49.38 & 53.85 & 59.58 & 56.18 & 55.34 & 51.46 & 50.45 & 49.34 & 46.85 \\
\hline Chloride mg/l & 29.84 & 27.68 & 24.55 & 22.76 & 21.49 & 22.14 & 17.32 & 18.54 & 21.38 & 22.53 & 26.42 & 31.24 \\
\hline Nitrate & 2.78 & 2.88 & 2.64 & 2.74 & 2.81 & 2.56 & 2.88 & 6.84 & 9.52 & 8.38 & 7.24 & 6.36 \\
\hline $\mathrm{Ca}^{++}$ & 39.52 & 38.74 & 37.55 & 36.84 & 37.18 & 34.25 & 33.88 & 49.85 & 47.56 & 48.16 & 39.72 & 37.68 \\
\hline $\begin{array}{c}\text { Total } \\
\text { Hardness }\end{array}$ & 76.28 & 70.16 & 83.44 & 104.54 & 134.36 & 146.62 & 148.34 & 130.18 & 126.52 & 118.74 & 105.34 & 78.52 \\
\hline Free $\mathrm{CO}_{2}$ & 4.74 & 5.92 & 6.68 & 6.74 & 6.81 & 7.46 & 6.78 & 6.58 & 6.51 & 6.38 & 5.84 & 5.56 \\
\hline
\end{tabular}

\section{Water Temperature}

Water temperature of pond water near R.K. College ranged between $15^{\circ} \mathrm{C}$ to $35^{\circ} \mathrm{C}$, while in the other pond this ranged between $14^{0} \mathrm{C}$ to $36^{\circ} \mathrm{C}$. Here the lowest temperature was found during winter while the highest during summer. Water temperature may accelerate or slow down the rate of the chemical reactions in the aquatic life forms. From the table it may be noted that from the month of February to June there was gradual increase in temperature, due to rise in atmospheric temperature. Due to rainy season the atmospheric temperature lowered and this was also true for the water temperature too. The higher temperature of the outside pond than the pond near R.K. College may be due to its open area as there were no shading devices. Pond mean R.K. College is surrounded by the buildings and big trees, so shading of the pond water was noted. Present findings are in agreement with the findings of Singh (2010), Goswami et al., (2017). Ramnathan and Amsath (2018) who also reported higher range of temperature during summer and lowest during winter.

\section{Turbidity}

From the table 1 , it is clear that the value of turbidity ranged between $35.0 \mathrm{NTU}$ to $48.0 \mathrm{NTU}$ in the water of pond near R.K. College and 33.0 NTU to 46.0 NTU in the water of pond situated outside the town. In both the ponds higher range of turbidity was found in the month of May and lowest in the month of November. Further the turbidity range was higher in the pond water near R.K. College, which may be correlated with the fact that this pond constantly gets domestic wastes as it is surrounded by the dense population where as the pond in outer location gets no such materials. Turbidity is the amount of suspended matter present in ay water body. Higher the concentration of total suspended solids higher will be the turbidity. Turbidity found here is supported by the findings of other workers such as Srivastva and Srivastva (2011), Tidame and Shinde (2012), Ramanathan and Amsath (2018).

\section{Transparency}

Transparency of water body signifies the depth up to which the light can penetrate into the water. Transparency of the both the pond water was determined. Maximum transparency $150.0 \mathrm{~cm}$ was observed in calm water of the pond near R.K. College in the month of January. In the same month., the transparency of pond water situated outside the town was $142.0 \mathrm{~cm}$. Similarly, the minimum transparency that was noted in the month of June in both the pond was 56 and $48 \mathrm{~cm}$ respectively. Reduced transparency during summer may be associated with the concentrations of inorganic substances. During rainy season they were diluted so gradually transparency increased. During winter these particles generally settle down, so maximum transparency was observed. Similar, results have been observed by workers like Sahni and Yadav (2012), Rahman et al., (2017), Sharma et al., (2017), Durge et al., (2018) etc. Therefore, these findings authenticate the present findings. 


\section{Alkalinity}

The ability to resist changes in $\mathrm{pH}$ is alkalinity, which is due to presence of carbonates, bicarbonates, hydroxides, phosphates and other compounds in water (Bhatnagar \& Pooja, 2013). In the present study as noted in table-1, alkalinity ranged between 133.62 to 156.48 and 131.78 to 151.24 respectively. Here higher range was obtained in summer and lowest in winter in both the ponds. The variation of total alkalinity was seasonal as it rose in summer and fell in winter. Maximum value of alkalinity in summer may be correlated with the fact that in summer, there is higher degradation of debris and organic waste. Increase in concentration of carbonate and bicarbonate thereby also increase the alkalinity of water. Biswas et al., (2011) also observed similar result in a pond of Burdwan municipality, West Bengal. Above findings are also supported by the findings of Bhattacharyya (2018).

\section{Total Dissolved Solids}

Water is generally called as the universal solvent. Large numbers of minerals metals, organic matters, inorganic salts mainly calcium, magnesium, sodium, potassium, chloride etc. (size less than 2 microns) are dissolved in it. (Charkhabi and Sakizadeh, 2006). Sewage, waste water and other organic and inorganic substances the source of total dissolved solids. In the present study monthly variation sin the contents of total dissolved solids were found in both the ponds.

As noted in table 1 , maximum amount of total dissolved solid was found in the month of June that was $1284 \mathrm{mg} / \mathrm{l}$ in the pond near R.K. College, where as it was $1228 \mathrm{mg} / 1$ in outside pond. Similarly, minimum amount was $948 \mathrm{mg} / 1$ in the month of September in one pond while it was $889 \mathrm{mg} / \mathrm{l}$ the month of October in other pond. Present findings corroborate with the findings of Barai and Kumar (2012), Majumdar and Dutta (2014), Swarnkar and Chaubay (2016), Sharma et al., (2017).

\section{Dissolved Oxygen}

It is the amount of free molecular oxygen dissolved in water. Main sources of dissolved oxygen in water bodies include air and phytoplanktons. In above two ponds monthly variations in dissolved oxygen were studied. As mentioned in table 2, it was noted that maximum value $8.52 \mathrm{mg} / 1$ was found in the month of January while the minimum value $4.76 \mathrm{mg} / \mathrm{l}$ was found in the month of June in the pond water near R.K. College while it varied between $8.64 \mathrm{mg} / \mathrm{l}$ in the month of January and $4.18 \mathrm{mg} / \mathrm{l}$ in June respectively. Water temperature is a physical parameter that significantly regulates the dissolved oxygen in water. Here in cold water oxygen dissolved maximum than the warmer water. Present findings are in agreement with the findings of Sahni and Yadav (2012), Mohan et al., (2013), Mazumdar and Dutta (2014), Quareshimatva et al., (2015), Rahman et al., (2017) and Durge et al., (2018).

\section{Free Carbon Dioxide}

Monthly variations in carbon dioxide were also calculated. As mentioned in table 2, the amount of free carbon dioxide was maximum $7.38 \mathrm{mg} / \mathrm{l}$ in the month of June, while it was the minimum $4.56 \mathrm{mg} / \mathrm{l}$ in the month of January in pond water near the R.K. College, while it was $7.46 \mathrm{mg} / \mathrm{l}$ in the month of June and 4.74 in the month of January. The lower value may be due to maximum utilization in photosynthesis and hither values may be due to minimum utilization of free carbon dioxide by the process of photosynthesis.

Present findings are in agreement with the findings of Sahni and Yadav (2012), Prasath et al., (2013), Dixit et al., (2015), Bano et al., (2016), Goswami et al., (2017) and Durge et al., (2018).

\section{Biological Oxygen Demand}

It is a measure of amount of oxygen needed by the microorganisms to decompose the organic matters present in a water body. Biochemical oxygen demand was measured on the monthly basis between January to December. From the table 2, it may be noted that the value ranged between $28.36 \mathrm{mg} / 1$ to $42.28 \mathrm{mg} / \mathrm{l}$. Here the minimum value was noted in the month of January, while the maximum in the month of May in the pond water near R.K. College, Madhubani. In the outer pond this value ranged between $28.58 \mathrm{mg} / \mathrm{l}$ to $42.78 \mathrm{mg} / \mathrm{l}$ in the month of January to June respectively. Above findings corroborate with the findings of Singh (2010), Kedar and Patil (2011), Thimupathaiah et al., (2012), Srivastva and Kanungo (2013), Reddy et al., (2015), Sharma et al., (2017) and Durge et al., (2018).

\section{Chemical Oxygen Demand}

It measured the amount of oxygen needed to oxidize the inorganic chemicals present in the water body. COD was also studied on monthly basis in both the ponds from January to December.

From the table 2, it may be noted that the value ranged between $38.85 \mathrm{mg} / \mathrm{l}$ to $58.74 \mathrm{mg} / \mathrm{l}$ in the water of the pond near R.K. College, Madhubani, while the outer pond water it was noted $39.64 \mathrm{mg} / \mathrm{l}$ to $59.68 \mathrm{mg} / \mathrm{l}$. Here in 
both the ponds the minimum value was found in the month of January while the maximum in the month of May respectively. Similar results have been reported by Singh (2010), Kedar and Patil (2011), Thimupathaiah et al., (2012), Srivastva and Kanungo (2013), Reddy et al., (2015), Sharma et al., (2017) and Durge et al., (2018). So the present findings are authenticated by the above workers.

\section{Chloride Contents}

Chloride ions are found in low concentrations in fresh water. This may be either due to natural or anthropogenic causes. Chloride ions in fresh water are basically added due to sewage contamination and addition of fertilizers residues such as potassium chloride etc. Chloride ions contents of both the above ponds were studied at monthly basis. From the table-2, it was clear that in pond near R.K. College revealed a monthly fluctuation which ranged between $15.78 \mathrm{mg} / 1$ to 29.62 $\mathrm{mg} / \mathrm{l}$.

Similarly, in the pond situated outside the town revealed monthly variations between 17.32 to 31.24 . The minimum concentration in both the ponds was noted in the month of July while the maximum in the month of December respectively. The highest value in outside pond may be due to the runoff from the nearby agricultural lands. In the pond near R.K. College may be due to the release of sewage from the surrounding areas. Present findings corroborate with the findings of Singh (2010), Biswas et al., (2011), Thirupathaiah et al., (2012), Yadav et al., (2013), Singh (2014), Reddy et al., (2015), Uddin et al., (2016), and Rahman et al., (2017). At low concentration chloride ions are harmless but at higher concentration it can harm the aquatic organisms.

\section{Calcium}

It is found in greater abundance in all natural water and its main source is the chemical fertilizers and decomposition of the matter containing calcium. From the table-2, it was clear that pond water near R.K. College revealed monthly fluctuation in calcium concentrations that was between $32.74 \mathrm{mg} / 1$ to $48.64 \mathrm{mg} / \mathrm{l}$, in pond situated outside revealed variations between $33.88 \mathrm{mg} / 1$ to $49.85 \mathrm{mg} / 1$. Here the lower concentrations were noted in the month of July, while higher in August in both the pod. In outside pond runoff from agricultural field might have added calcium as the residue of chemical fertilizers. Similar patterns of variations have been reported by Sahni and Yadav (2012), and Thangamalathi and Anuradha (2018).

\section{Total Hardness}

This is caused by mainly due to the presence of calcium and magnesium. Although ions of iron, zinc, manganese etc. also contribute in the hardness but due to their lower concentrations their contribution is not much significant. From the table-2, it may be noted that, pond water near R.K. College had maximum hardness 151.60 $\mathrm{mg} / \mathrm{l}$ in the month of June while minimum 72.38 was found in February. In the same month maximum hardness of outside pond water was $146.62 \mathrm{mg} / \mathrm{l}$ and minimum $70.16 \mathrm{mg} / 1$ respectively. During summer the volume water is reduced and naturally the chemical concentrations will be increased. While during winter the volume increases due to addition of water during rainy season and there is less evaporation. Present findings corroborate with the findings of Sahni and Yadav (2012), Tidame and Shinde (2012), Durge et al., (2018), and Ramanahan and Amsath (2018). Therefore, these findings are authenticated with the findings of different workers.

\section{CONCLUSION}

Present study was conducted to find out the monthly variations in selected physico-chemical parameters of tow ponds of Madhubani town situated at different location. The pond near R.K. College is surrounded by dense populations and the sewage and other domestic solid wastes are being dumped in it. Due to this the quality of water is degrading day by day. The pond outside the town is surrounded by agricultural lands. During rainy season the pond gets water from these fields. Such water carried residue of different agrochemicals. They are being deposited every year and this is not good for the health of the water of the pond. The data obtained here may help in the management of these water bodies because, purity of water is essential for both the flora and fauna.

\section{ACKNOWLEDGEMENT}

The authors are thankful to the Principal of M.L.S.M. College, Darbhanga for providing necessary facilities during this research work.

\section{REFERENCES}

APHA, 2005. Standard methods for examination of water and waste water. $21^{\text {st }}$ Edn. Washington D.C.

Balkrishnan S., Chelladurai G., Mohan Raj J. and Poongodi J., 2017. Seasonal variations in physico-chemical characteristics of Tuticorin 
coastal waters, South East Coast, India. Applied Water Science, 7(4): 1881-1886.

Bano Z., Chauhan R. and Bhatt N.A., 2016. A study of seasonal physico-chemical parameters in river Narmada. Journ. of Chem, Biol. and Physical Sci., 6(1): 10-17.

Bhatnagar A. and Devi P., 2013. Water quality guidelines for the management of pond fish culture. Int. J. of Env. Sci., 3(6): 1980-2009.

Bidisha Bhattacharyya (Nec) Ghosh, 2018. Physical chemical analysis of pond water in Purba Bardhaman, West Bengal, India. Int. Res. J. Environ. Sci., 7(2): 54-59.

Biswas P., Vardi H.K. and Ghosh A., 2011. Physicochemical analysis of small reservoir Budha Talab in Raipur. Adv. in Aquat. Ecol., 5: 111121.

Charkhabi A.H. and Sakizadeh M., 2006. Assessment of spatial variation of water quality parameters in the most polluted branch of Anzali Wetland, Northern Iran. Polish Journ. of Environ. Stud., 15(3): 395-403.

Dixit A.K., Pandey S.K., Mehta R., Ahmad N.G. and Pandey J., 2015. Study of physico-chemical parameters of different ponds water of Bilashpur district, Chhattisgarh, India. Environ. Skeptics and Critics, 4(3): 89-95.

Durge L.S., Chilke A.M. and Chauhan R.N., 2018. Seasonal variations in the physico-chemical parameters of Malgujari pond of Ghugus district Chandrapen, Maharashtra. Int. Journ. of Scie. Res. in Bio-Sci., 5(5): 52-57.

Goswami S.N., Trivedi R.K., Saha S. and Mandal A.J., 2017. Seasonal variations of water characteristics in three urban ponds with different management practices at Kolkata at West Bengal, India. Journ. of Ent. \& Zool. Stud., 5(6): 149-1454.

Kedar G.T. and Patil G.P., 2011. Study on seasonal fluctuation in physico-chemical parameters of Rishi Lake Karanja, Distt. Maharashtra. NCEBB, pp-120-122.

Kiran B.R., 2010. Physico-chemical characteristics of fish ponds of Bhadra project at Karnataka. Rasayan J. of Chemistry, 3(4): 671-676.
Mahananda R., Mohanthy B.P. and Behera N.R., 2010. Physico-chemical analysis of surface and ground water of Bargarh District, Orissa, India. Int. J. Recent Res. and Appl. Stud., 2(3): 284-295.

Mazumdar S. and Datta T.K., 2014. Studies on seasonal variations in physico-chemical parameters in Bankura segment of Dwarakeshwar River, W.B., India. Int. J. of Adv. Res., 2(3): 877-881.

Mishra K., Pandey M. and Devendra N., 2013. An assessment of the physico-chemical characteristics of Bhamka Pond, Rewa District, India. Eng. and Technol., 2: 1781-1788.

Mishra S., Singh L.A. and Tiwari D., 2014. Studied of physico-chemical status of Ponds at Varanasi Holy city under Anthropogenic influences. Int. J. of Environ. Res. and Develop., 4: 261-268.

Mohan V.C., Sharma K.K. and Sharma A., 2013. Limnological profile of Chennai Hydroelectric Reservoir, its connecting channel and river Tawi in Udhampur district of Jandk, India. Int. Res. J. of Biol. Sci., 2(3): 76-79.

Nag A. and Gupta H., 2014. Physico-chemical analysis of some pond water in and around Santiniketan, West Bengal, India. Int. J. of Environ. Sci., 4(5): 676-682.

Parikh A.N. and Mankodi P.C., 2012. Limnology of Sama Pond, Vadodra city, Gujarat. Res. J. Rec. Sci., 1(1): 16-21.

Patel V. and Parikh P., 2013. Assessment of seasonal variations in water quality of river Mini at Sindhrot, Vadodara. Int. J. of Environ. Sci., 5: 1424-1436.

Paul D.K., Sanyal S., Swarna S. and Kumari R., 2015. Impact of Saraswati Idol immersion on the water quality of Ganga River at Patna (Bihar). J. of Pat. Sci. College, 3: 147-162.

Pejawar, Madhuri, Vaishali Somani and Quadros G., 2004. Physico-chemical parameters of two quarry lakes near Thane City, Maharashtra. J. Aqua. Biol., 19(1): 107-110.

Prasath B.B., Nand Kumar R., Kumar S.D., Ananth S., Devi S., Jayalakshami T., Raju P., Thiyagrajan M. and Santhanane P., 2013. Seasonal variations in physico-chemical characteristics of pond and ground water of Tirulhirapali, India. Journ. of Environ. Biol., 34: 529-537. 
Qureshimatva U.M., Maurya R.R., Gamit S.B., Patel R.D. and Solanki H.A., 2015. Determination of physico-chemical parameters and water quality index (WQI) of chandlodia lake, Ahmadabad, Gujarat, India. Journ. of Haem. and Ecotoxic., 5: 288-294.

Rahman A.K.M.F., Mansur M.A. and Rahman M.S., 2017. Monthly and diurnal variations of limnological conditions of two ponds. Int. J. Agril. Res. Innov. \& Tech., 7(1): 14-20.

Ramanathan S.A. and Amsath, 2018. Seasonal variations in physico-chemical parameters of Puthukulam pond, Pudukkottai, Tamilnadu. Res. J. Life Sci. Bioinformt., Pharma. \& Chem. Sci., 3: 01-07.

Reddy G.S., Balakrishna D. and Reddy T.R., 2015. A study of physico-chemical parameters and fish diversity of Nizam Sagar Dam, Nizamabad, Telangana. Int. J. of Fish. and Aquat. Stud., 3(2): 248-254.

Sahni K. and Yadav S., 2012. Seasonal variations in physico-chemical parameters of Bharawas pond, Rewari, Haryana. Asian J. Exp. Sci., 26(1): 6164.

Sharma I., Dhanze R. and Rana P., 2017. Physicochemical parameters of lentic water bodies from Mid-Himalayan region (H.P.), India. Int. J. of Fish. and Aquat. Stud., 5(2): 674-678.

Singh N., 2010. Physico-chemical properties of polluted water of river Ganga at Varanasi. Energy and Environment, 1(5): 823-832.

Singh P., 2014. Studies on seasonal variations in physicochemical parameters of river Gomati, U.P., India. Int. J. Adv. Res., 2(3): 877-881.

Smitha P.G., Byrappa K. and Ranaswamy S.N., 2007. Physico-chemical characteristics of water samples of Bantwa Taluk, South Western,
Karnataka, India. J. of Environ. Biol., 28: 591595.

Srivastva A. and Srivastva S., 2011. Assessment of physico-chemical properties and sewage pollution indicator bacteria in surface water of river Gomati in Uttar Pradesh. Int. J. Environ. Sci., 2: 325-336.

Srivastva S. and Kanungo V.K., 2013. Physico-chemical analysis of pond water of Surguja District, Chhattisgarh, India. Int. J. of Herb. Med., 1(4): $35-43$.

Swarnkar A.K. and Chaubay S., 2016. Testing and Analysis of pond water in Raipur City, Chhattisgarh, India. Int. J. Sci. \& Res., 5: 19621965.

Tank S.K. and Chippa R.C., 2013. Analysis of water quality of Halena Block in Bharatpur area. Int. J. of Sci. Res. Publ., 3: 115-118.

Thirupathaiah M., Samatha C.H. and Chintha S., 2012. Analysis of water quality using physicochemical parameters in lower Manair reservoir of Karim Nagar district, Andhra Pradesh. Int. J. of Environ. Sci., 3(1):172-180.

Uddin M.G., Mondruzzaman M., Allah M. and Khan A., 2016. Seasonal variations of physico-chemical properties of water in the BudhiGanga River, Bangladesh. World. Applied Sci. Journ., 34(1): 24-34.

Verma P.U., Purohit A.R. and Patel N.J., 2012. Chanlodia lake water analysis, located in Ahmadabad, Gujarat. Int. J. of Eng. Res. and Appl., 2: 16001610

Yadav P., Yadav V.K., Yadav A.K. and Khare P.K., 2013. Physico-chemical characteristics of a fresh water pond of Orai, U.P. Central India. Octa. J. of Biosci., 1: 177-184. 